\title{
EXPERIMENTAL INVESTIGATION OF THE INFLUENCE OF MULTI-RECYCLING ON THE FRACTURE BEHAVIOR OF POST CONSUMER HIGH IMPACT POLYSTYRENE FROM DISPOSABLE CUPS EVALUATED BY THE J-INTEGRAL APPROACH
}

\author{
Hanan El Bhilat ${ }^{1 *}$, Hassan MABChOUR ${ }^{2}$, Houda Salmi, ${ }^{1}$, \\ Abdelilah HaChim ${ }^{2}$ AND KHALID El HAD ${ }^{2}$ \\ ${ }^{I}$ National higher school of electricity and mechanics, ENSEM, Laboratory of Control and \\ Mechanical Characterization of Materials and Structures, Casablanca, 20232, Morocco. \\ ${ }^{2}$ Institute of Maritime Studies, Laboratory of Materials and Structures, \\ Casablanca, 20232, Morocco. \\ *Corresponding author: h.elbhilat@ensem.ac.ma.
}

(Received: $11^{\text {th }}$ November 2020; Accepted: $5^{\text {th }}$ September 2021; Published on-line: $4^{\text {th }}$ January 2022)

\begin{abstract}
The aim of the present paper is to study the effect of multi-recycling on the fracture behavior of high impact polystyrene from disposable cups. After collecting and washing the material, it was subjected to six cycles of recycling. After each cycle, it was subjected to tensile tests to determine the R-curves. The theory of the J-integral contour has been used for the development of a characterization method of the fracture strength appropriate to the case of this non-linear elastoplastic polymer material. To this end, the method of multiple specimens (Single edge notch tension SENT) of thin thickness was used, by introducing cracks of the same lengths to several identical test pieces. The results suggested a slight decrease in crack resistance of recycled high impact polystyrene, especially during the first cycle, demonstrated by a comparison of $\mathrm{J}_{\mathrm{IC}}$ values related to initiation of crack propagation. The fracture energy absorbed as a function of the cycles suggested a weakening within the material.
\end{abstract}

ABSTRAK: Tujuan kajian ini adalah bagi mengkaji kesan tindak balas pada pelbagai peringkat-kitar semula ke atas kerapuhan polisterin berimpak tinggi pada cawan pakai buang. Selepas mengumpul dan membasuh cawan ini, terdapat enam peringkat kitar semula. Pada setiap peringkat, ianya akan melalui ujian tegangan bagi mendapatkan lengkung-R. Teori kamiran-J kontur telah digunakan bagi mencipta kaedah khas bagi mengkaji kekuatan retakan bersesuaian bagi kes bahan polimer elastoplastik yang tidaklinear. Sehingga kini, kaedah Regangan Tepi Takuk Tunggal (SENT) telah digunakan pada spesimen berketebalan rendah, dengan menghasilkan keretakan sama panjang di permulaan kajian di buat pada pelbagai bahan uji yang serupa. Dapatan kajian menunjukkan rintangan pada retakan telah berkurang sedikit pada polisterin kitar semula berimpak tinggi, terutama pada kitaran pertama, yang ditunjukkan pada nilai $\mathrm{J}_{\mathrm{IC}}$ pada permukaan rambatan retakan awal. Tenaga kerapuhan yang meresap pada setiap kitaran menunjukkan bahan telah melemah dari dalam.

KEYWORDS: recycling; high impact polystyrene; fracture; J-integral; extrusion 


\section{INTRODUCTION}

The 19th and 20th centuries marked the appearance of plastics. These new materials are the result of advances in petrochemicals and awakened a particularly strong interest in the aftermath of the Second World War, a period during which the industry had to cope with the growing demand for raw materials. Consequently, the various properties, ease of processing, and advantageous costs presented by these materials encourage their application in all fields of industrial production in order to meet the growing needs of consumers.

The oil shock occurring in the 1970s marked the beginning of consumer polymers. However, this massive exploitation is not without consequences. Indeed, the main drawback of polymeric materials lies in the fact that they are not biodegradable and thus create the problem of managing their industrial or consumer waste, which accumulates in a worrying manner. It is only in the last thirty years that the treatment of plastic waste has become a primary concern in preserving the environment. The recovery of plastic materials is then the subject of all attention, especially in the scientific world where many studies have looked at this global phenomenon.

The general characteristics of plastic waste and recycled polymers, from a mechanical point of view, are established by the fact that they have undergone, during their previous uses, two major phenomena. On the one hand, used or recycled polymeric resins have experienced degradation due to aging (fatigue, temperature...), oxidation, or water absorption. This degradation is manifested by chain breaks and crosslinks occurring at the level of macromolecules. The consequence of these phenomena is the gradual deterioration of the thermomechanical properties of plastic materials [1-5]. On the other hand, pollution depending on the clean or dirty origin of the previous use of this waste can lead to a retention of impurities which influences, among other things, negatively, their thermal and mechanical properties.

Although these two factors are closely linked, their more or less extensive existence depends, of course, on the origin of the waste. For example, it makes perfect sense that industrial plastic waste undergoes very little degradation and has extremely low impurities. Their existence and influence may even turn out to be negligible with regard to production waste (directly from polymerization reactors). Too high temperatures or even too long a residence time could have a degradation effect [6-10]. That's why this paper is only focused on the influence of multi-recycling on the fracture behavior of high impact polystyrene.

High impact polystyrene (HIPS), is a specific polystyrene because of its opacity and above all, its impact resistance. It is also called impact polystyrene (SB). Styrene is the basic element in the manufacture of polystyrene and its compatibility with other monomers and polymers makes it possible to imagine many styrenic compounds with various properties. HIPS is one of them. It incorporates 15 to $25 \%$ polybutadiene and is also obtained by grafting polybutadiene during the production of polystyrene. HIPS is an inexpensive plastic material that is easy to produce and shape. Thus, it has a wide forming temperature range and is particularly suitable for thermoforming. In addition, it can have a glossy, satin or matte finish. It is also easily pigmentable; characteristics that make impact polystyrene widely used in various fields. It is used to manufacture displays, containers, toys, roof boxes, food packaging, etc.

Most of the scientific articles treating the influence of recycling on thermoplastics are interested in mechanical properties in particular: elongation at break, elastic limit, maximum stress and impact resistance. All of this data was determined by stress testing and pendulum impact testing in Charpy and Izod mode. Also, various analyses with a scanning electron 
microscope or even with an electronic transmission microscope have also been identified in certain works. The information found as a result of these tests was aimed at determining whether or not there was an improvement in mechanical properties [11-22]. However very limited studies have treated the elasto-plastic fracture behavior of post-costumer high impact polystyrene, especially in the case of multi-recycling. In this study, we investigated the effect of multi-recycling on the fracture behavior of high impact polystyrene from disposable cups, using the multi-specimen method that finds its application in Elastoplastic Fracture Mechanics.

A strained metal or polymer can undergo certain damage and alternations. This damage can lead, in some cases, to the appearance of macroscopic cracks. These cracks are often of sufficiently large size to satisfy the assumptions of continuity of the mechanics of a continuous medium. We can then place ourselves within the framework of fracture mechanics to characterize the harmfulness of this defect [23].

The goals of linear fracture mechanics are:

- The characterization of the stress fields and singular deformations at a crack point

- Establishing the relationships between the crack point fields, the geometry of the test specimen and the overall field (measurable quantity)

- The energy conditions necessary for the (re)-initiating of the crack

- Description of the crack propagation (stable or unstable)

- The determination of a critical size of the defects beyond which the failure (especially unstable) will be triggered

Initially, one will endeavor to present the cases where the factor $\mathrm{K}_{\mathrm{I}}$ : the factor of intensity of the stresses, and $G$ the rate of restitution of energy, provide solutions in the understanding of the initiation mechanisms of polymers. In this paper, we will then be interested in the parameter $J$ and its uses in fracture mechanics in the case where the material has a non-linear elastic behavior, which is the case of high impact polystyrene.

Unlike resilience, an integral characteristic depending on the experimental conditions, toughness is an intrinsic characteristic of materials and a quantity that can be used in design (like a Young's modulus). The determination of the toughness is carried out on specimens notched by different theoretical approaches depending on the mechanical behavior of the material. Indeed, for a brittle material, toughness is evaluated from the concepts of Linear Elastic Fracture Mechanics (LEFM) while it is studied according to the concepts of Elastoplastic Fracture Mechanics (Post-Yield Fracture Mechanics: PYFM) when the material is ductile.

PYFM requires the introduction of the concept of Cracking Resistance curve or R curve. It was established by Irwin [24] in order to characterize the resistance to slow cracking of materials with some ductility at the crack head. An R curve is a curve of variation of the toughness with the crack advance $(\Delta \mathrm{a})$. In general, a crack can start and then progress when a parameter $(\mathrm{K}, \mathrm{G}$, or $\mathrm{J})$, representing the action of the external environment at the crack head, becomes equal to the resistance to cracking (KR, GR, or JR) of the material. In the case of a brittle material (LEFM), the structure of the material and its resistance to cracking do not change during propagation due to the absence of plastic deformation at the crack head. On the other hand, in the case of a ductile material (PYFM), the progressive increase in the plastic deformation at the crack head during initiation and propagation causes an increase and then a stabilization of its resistance to cracking. The toughness of the material 
can no longer be represented by a single critical parameter $\left(K_{c}\right.$ or $\left.G_{c}\right)$ but rather by an $R$ curve $(K R$, GR or JR $=\mathrm{f}(\Delta \mathrm{a}))($ Fig. 1$)$.
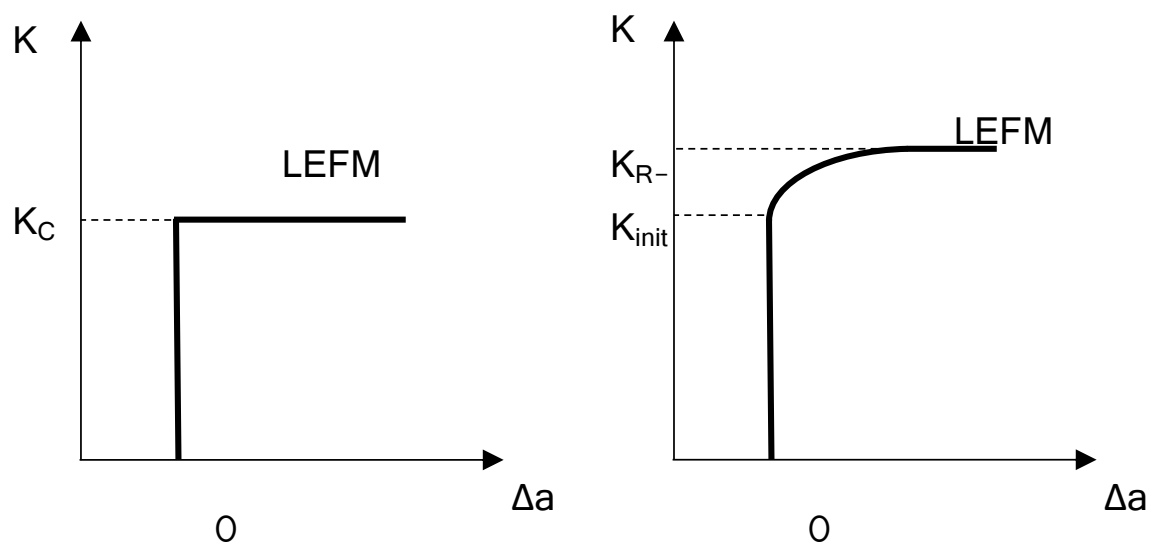

Fig. 1: R curves in LEFM and PYFM.

Rice [25] demonstrated that, in the case of a crack located in the xz plane and whose front is parallel to the axis $\mathrm{z}$ (Fig. 2), the integral J (Eq. (1)) is independent of contour $\Gamma$ and null when this contour is closed (there is no crack). We can consider that $\mathrm{J}$ represents the component of the energy flow crossing $\Gamma$, due to the singularity related to the presence of the crack.

$$
J=\int_{\Gamma}\left(W d y-T_{i} \frac{\partial u_{i}}{\partial x} d s\right)
$$

with: W, the strain energy density,

$\mathrm{T}_{\mathrm{i}}$ the outwardly oriented traction vector,

$\mathrm{u}_{\mathrm{i}}$, the displacement vector of the arc ds,

$\mathrm{s}$, the curvilinear abscissa on the contour $\Gamma$,

$\mathrm{x}, \mathrm{y}$ and $\mathrm{z}$ the Cartesian coordinates.

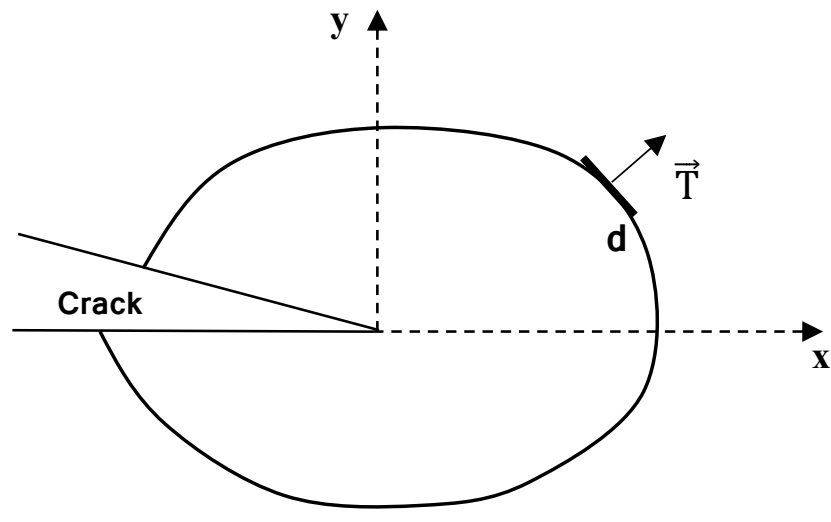

Fig. 2: Illustration of the concept of integral J.

Note that $\mathrm{W}=\int \sigma_{\mathrm{ij}} \mathrm{d} \varepsilon_{\mathrm{ij}}$, with $\sigma_{\mathrm{ij}}$ and $\varepsilon_{\mathrm{ij}}$ the stress and strain components, respectively. 
$\mathrm{J}$ is calculated from the energy $\mathrm{U}$ necessary to propagate the crack (energy supplied by the external environment) (Eq. (2)).

$$
J=-\frac{1}{b} \frac{d U}{d a}
$$

with "b", the thickness of the specimen and "a" the crack length. From this equation (Eq. (2)), Begley and Landes [26-28] have shown that $\mathrm{J}$ is identical to $\mathrm{G}$ in the case of a linearly elastic and brittle material and that $J$ can be a criterion of rupture for elastoplastic materials. The crack is initiated when $J$ reaches a critical value $J_{I C}$ which is an intrinsic characteristic of the material. Although $\mathrm{J}_{\mathrm{IC}}$ 's calculation methods are very controversial, the ASTM E813-81 standard that considers the case of metals seems to be applicable to polymers. This standard assumes that the curve $J=f(\Delta a)$ is a line and that $\mathrm{J}_{\mathrm{IC}}$ corresponds to the intersection of this line with the blunt line (Fig. 3) having for equation:

$$
J=2 \sigma_{y} \Delta a
$$

with $\sigma_{y}$ being the stress at the tensile yield point of the material. On the other hand, the ASTM E 813-87 standard states that the curve $J=f(\Delta a)$ follows a power law of the form $J$ $=A \cdot \Delta \mathrm{a}^{\mathrm{n}}$ and that $\mathrm{J}_{\mathrm{IC}}$ corresponds to the value of $\mathrm{J}$ taken at the intersection of this curve with the straight line of Eq. (4)(Fig. 3):

$$
J=2 \sigma_{y}(\Delta a-0,2 m m)
$$
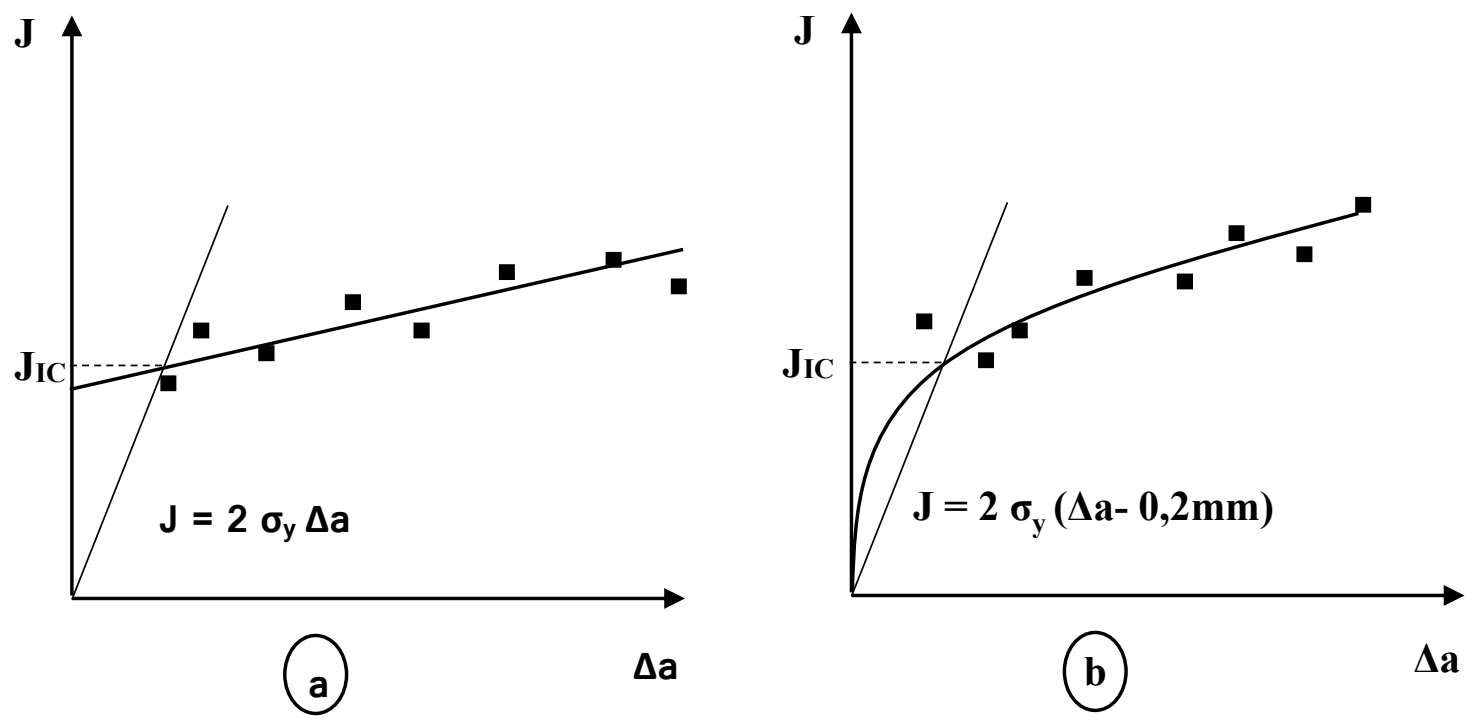

Fig. 3: Method for determining $\mathrm{J}_{\mathrm{IC}}$ according to ASTM E 813-81 (a) and ASTM E 813-87 (b).

In practice, the procedure for obtaining J-R curves is identical to that used in LEFM. To construct the J-R curves, it is necessary to perform the tests on multiple samples ( 7 minimum) up to different levels of deflection or crack opening. These tests will be followed by an optical measurement of the fracture surface in order to determine the actual crack advances. Each test piece tested leads to the determination of a pair of values (J, $\Delta \mathrm{a})$, i.e. at a point on the J-R curve. Next, we calculate the integral $\mathrm{J}$. 


\section{MATERIALS AND METHODS}

In this section, we present our experimental study, divided into two parts:

- The first is to study the effect of several extrusion/recycling cycles on the toughness properties of high impact polystyrene from disposable cups, mainly the $\mathrm{J}-\Delta$ a curves.

- The second is devoted to the study of the effect of the six recycling cycles on the $\mathrm{J}_{\mathrm{IC}}$ parameter then compare the results to virgin material.

The work plan thus followed is presented below. The various experimental techniques used and their operating conditions, as well as the ways of using the results are also presented in this paper.

\subsection{Disposable Cups Recycling}

The high impact polystyrene disposable cups collected for this study by the recycling company have undergone mechanical recycling carried out at the level of the same recovery company.

The process involves washing and then shredding the cups into small pellets. These pellets are then crushed using a grinder. The granulation (Fig. 4) of the ground material obtained is carried out in a twin-screw granulating extruder by the material provider.

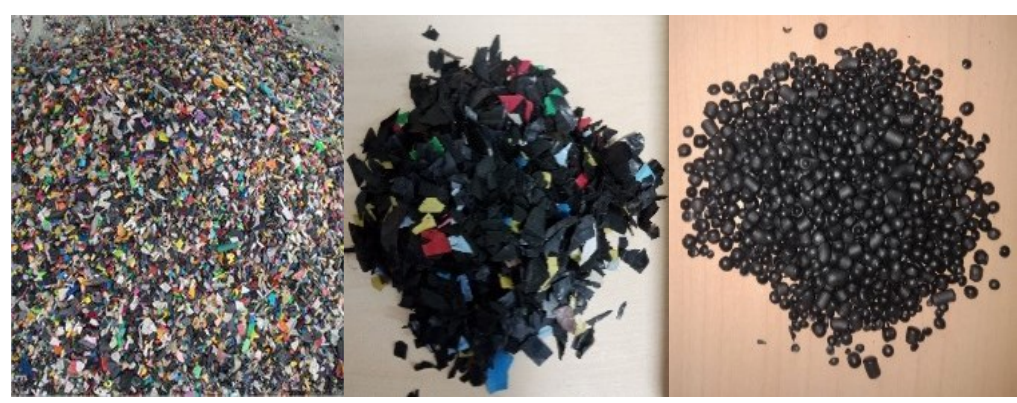

Fig. 4: HIPS Granules and pellets from disposable cups.

The extruder (Leistritz) is equipped with a cylinder filter changer. The filtering system helps prevent unmelted granules or other impurities from entering the extrudate. The extrusion parameters are as follows:

- Extrusion temperature: from 220 to $230{ }^{\circ} \mathrm{C}$;

- Screw speed: $35 \mathrm{rpm}$.

- A maximum injection pressure of 2,500 bars.

The extrudates are cooled in a water tank before being transformed into granules using a cutter. These granules, considered to be the first cycle of extrusion, are then made into specimens destined for various thermo-mechanical tests by molding process as shown in Fig. 5.

The specimens obtained are treated in the same way and with the same conditions described above. These operations were repeated six times without any change under all conditions. Therefore, the total number of extrusion cycles, to which the virgin resin is subjected, is equal to 6 . 


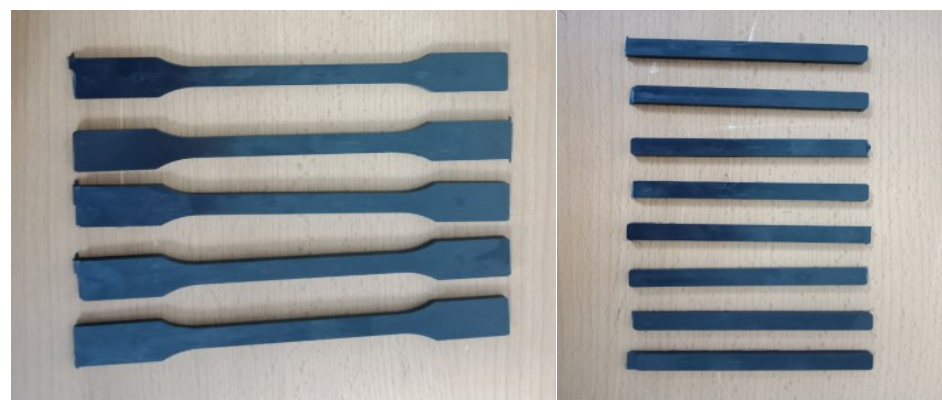

Fig. 5: Tests specimens according to ISO 294-1 and ISO 294-2.

\subsection{Choice of Specimens for Fracture Behavior Analysis}

The ISO 13586 and ASTM D 5045 standards suggest that to evaluate the $\mathrm{J}_{\mathrm{IC}}$ of a thermoplastic and thermosetting material, the tests must be carried out on CT (Compact Tension) specimens, or on SENT (Single Edge Notched Tension) specimens. The dimensions of the test pieces are given by the standards. Although the specifications and recommendations of the two standards ISO 13586 and ASTM D 5045 are only applicable for linear fracture mechanics, the choice and sizing of specimens has been maintained by standard ASTM D 6068 for the determination of JR curves of elastoplastic polymer materials. In our experimental study, the JR curve of both virgin and recycled high impact polystyrene is drawn by adopting the operating mode described by the standard ASTM D 6068 , but the general configuration of the test (type of test piece, experimental device, etc.) is identical to that performed in LEFM (ASTM D 5045, ISO 13586). The SENT (Fig. 6) specimens were molded by a SINTESI molding machine.
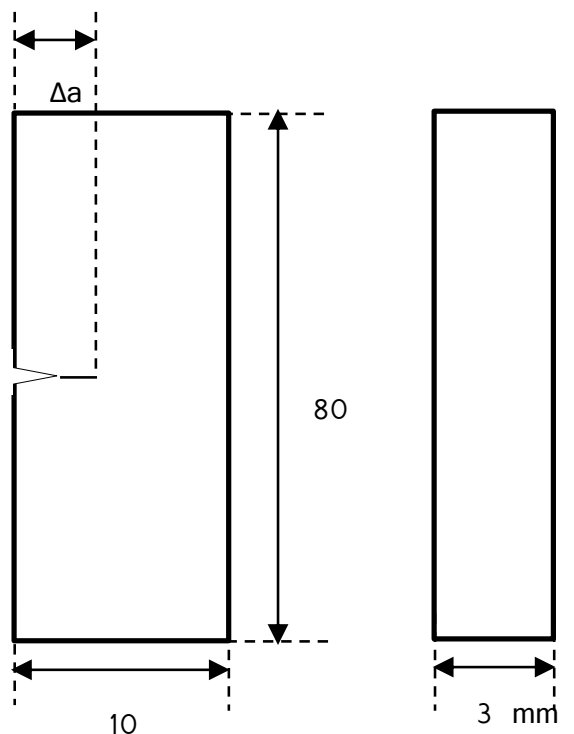

Fig. 6: Cracked tensile test piece on the side (SENT).

The last stage of preparation of the specimens is carried out using a razor blade. A precrack is introduced into the notched area of the specimen, the cutter blade of which, $0,4 \mathrm{~mm}$ thick, is changed after 5 specimens. The condition of the blade is essential to avoid residual stresses following this operation.

Un-notched SENT specimens were machined for tests that correct the results obtained on notched and pre-cracked specimens. 


\subsection{Test Methodology and J-R Curve}

The principle of the construction method of the experimental JR curve is to load a precracked specimen until an imposed displacement (displacement of the cross member), of the order of a few tenths of a millimeter, is reached with a fixed loading speed. The tensile tests were carried out using a ZwickRoell tensile machine with a 2,5 kN load cell.

The fracture face is then optically examined to calculate the advance of the crack. Consequently, two types of data are to be recovered on a test:

- The load displacement curve, which leads to calculate J.

- The fracture surfaces, which makes it possible to measure the crack advance $\Delta$ a.

The crack advance measurements, being of very low values, were performed with KSM off-line measuring device that measures thinly cut cross sections (slices) of specimens, as shown in Fig. 7.

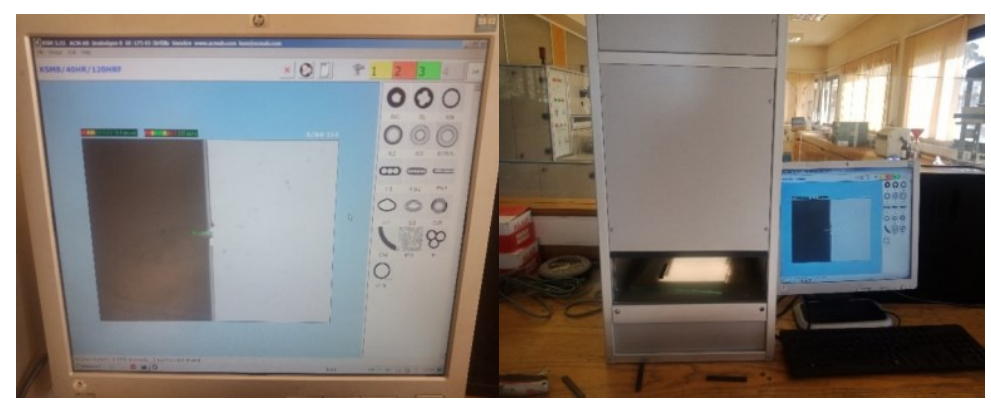

Fig. 7: KSM off-line measuring device.

Thus, each specimen makes it possible to obtain a pair of values $(\mathrm{J}, \Delta \mathrm{a})$ that represent a point on the J-R curve.

This method, shown in Fig. 8, (proposed by the ASTM D 6068) standard, provided that the loading speed adopted causes a clear and stable propagation of the crack. To ensure this condition, the ISO 13586 standard recommends using, at a temperature of $23^{\circ} \mathrm{C}$, a speed of $10 \mathrm{~mm} / \mathrm{min}$.

The $\mathrm{J}$ integral is calculated from the area under the load displacement curve - using Grapher 14 software, which represents the total energy $U_{T}$. A single tensile test is carried out on a non-notched SENT specimen of the same size as the notched specimen. The unique load displacement curve from this test is used to calculate the indentation energy " $U_{i}$ " for each specimen. Indeed, $U_{\mathrm{i}}$ is the area under the curve between zero until the displacement corresponding to the maximum force applied to the notched and pre-cracked specimen. This amount of energy is dissipated by phenomena other than cracking.

Using $U_{T}$ and $U_{i}$, J can be calculated for each test by Eq. (5):

$$
J=\frac{\eta\left(U_{T}-U_{i}\right)}{b\left(w-a_{0}\right)}
$$

$\eta$ is a geometrical dimensionless parameter. Garcia et al [29] state that to calculate $J$ of polymers, the factor $\eta$ depends only on the ratio between the length of the crack and the width of the specimen $\left(\mathrm{a}_{0} / \mathrm{w}\right)$.

For the geometry of the test piece, Clarke and Landes [30] succeeded in obtaining an approximation of $\eta$ through the formula:

For CT specimens 


$$
\eta=2+0,522\left(1-\frac{a_{0}}{w}\right)
$$

For SENT specimens

$$
\eta=2
$$

\subsection{Tests on SENT Specimens}

The SENT specimens are loaded by applying a tensile force through the two symmetrical bores and a suitable mounting on the ZwickRoell tensile machine equipped with a $2,5 \mathrm{kN}$ load cell. The test is stopped once the imposed displacement $(\mathrm{u})$ is reached (Fig. 8). The load-displacement curve is recovered and the cracking area is examined in the KSM instrument to facilitate the measurement of the different crack advance lengths $\Delta \mathrm{a}$. Finally, the test piece is completely torn into two parts.

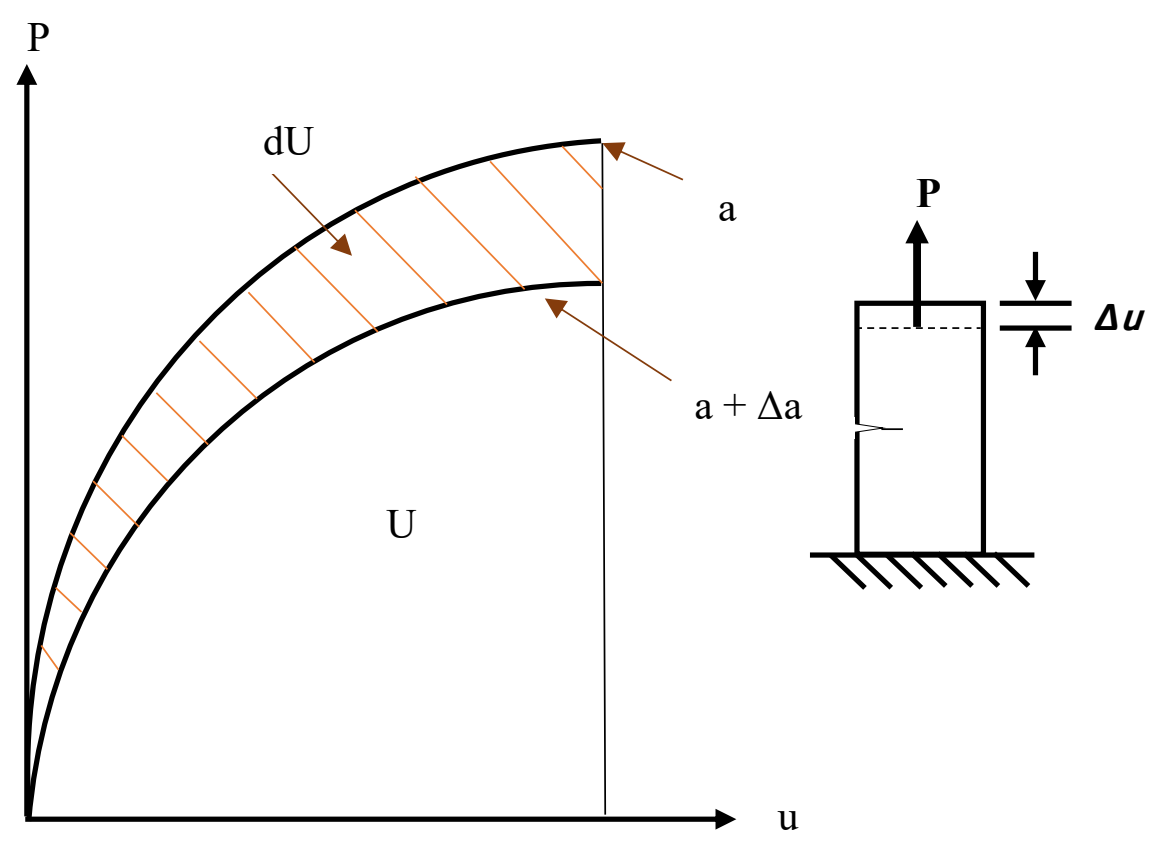

Fig. 8: Variation of dissipated energy with constant displacement.

Eight restraints $(\mathrm{u})$ are studied ranging from $2,5 \mathrm{~mm}$ to $10 \mathrm{~mm}$. For displacements smaller than $2,5 \mathrm{~mm}$, we did not observe an advance of the crack. The eight tries give us 8 points, with one or two extra specimens if needed. The standard requires a minimum of 7 points to draw the J-R curve. The maximum force and total energy are deduced and calculated from these curves. The values obtained are corrected by the indentation energy. So, $\mathrm{J}$ is calculated for each test specimen by applying Eq. (5).

The fracture areas of the two parts of the specimen are then observed. The depth of the pre-cracks (or initial crack) is not controlled during the preparation of the specimen, but measured precisely after each test under the KSM device. It is the average of three measurements of the distance between the notch tip and the crack tip. The distance between the final crack front and the initial crack front is measured at five equidistant points. The extension of the crack $\Delta \mathrm{a}$ is the average of this value.

The J-R curve given by the tensile tests on SENT specimens is plotted. This curve characterizes the resistance to cracking of HIPS. The most useful information that can be 
derived from this curve is the starting toughness $\mathrm{J}_{\mathrm{IC}}$, a characteristic of the material. It defines the initiation point of a crack.

The ASTM E 813 standard recommends, for the calculation of $\mathrm{J}_{\mathrm{IC}}$, a graphic method that consists of shifting the blunt line to a $\Delta \mathrm{a}=0,2 . \mathrm{J}_{\mathrm{IC}}$ is the intersection of this straight line with curve $\mathrm{J}$. In addition to the blunt line method, some authors define $\mathrm{J}_{\mathrm{IC}}$, for polymer materials, as the value of the curve $\mathrm{J}$ - $\Delta \mathrm{a}$ which corresponds to an advanced $0,2 \mathrm{~mm}$ or 0,4 mm crack [31,32]. HUAND [32] asserted that $\mathrm{J}_{0,2}$ can also be taken as the characteristic value representative of crack initiation.

\section{RESULTS AND DISCUSSION}

A significant shift is noted between the J-R curve given by the tests on test pieces of virgin HIPS, and that obtained with recycled material. On the other hand, a slight decrease of $\mathrm{J}_{\mathrm{IC}}$ is noticed amongst different cycles as shown in Fig. 9 and Fig. 10, thus demonstrating that the mechanical properties in terms of fracture energy, represented by the energy sufficient to initiate the fracture, decreases with the increase in the number of cycles performed. The material changes from a ductile state to a brittle state. Embrittlement occurs abruptly by the combined effect of the drop in molar mass and the increase in crystallinity (entanglement), thus reducing the amorphous phase, which prevents crack growth within the material.

Through the number of recycling cycles, high impact polystyrene undergoes thermomechanical-chemical degradation inducing chain scissions, the molar weight decreases creating more chain ends. These extremities represent concentrates of fracture energy that absorb the energy and cannot propagate it any longer, initiating the fracture. In addition, a large difference in molecular mass produces a heterogeneous whole favoring fracture. The low number of entanglements that were the usual consolidation of high impact polystyrene propagates the tear easily creating the fracture while the fracture of virgin HIPS was relatively difficult.

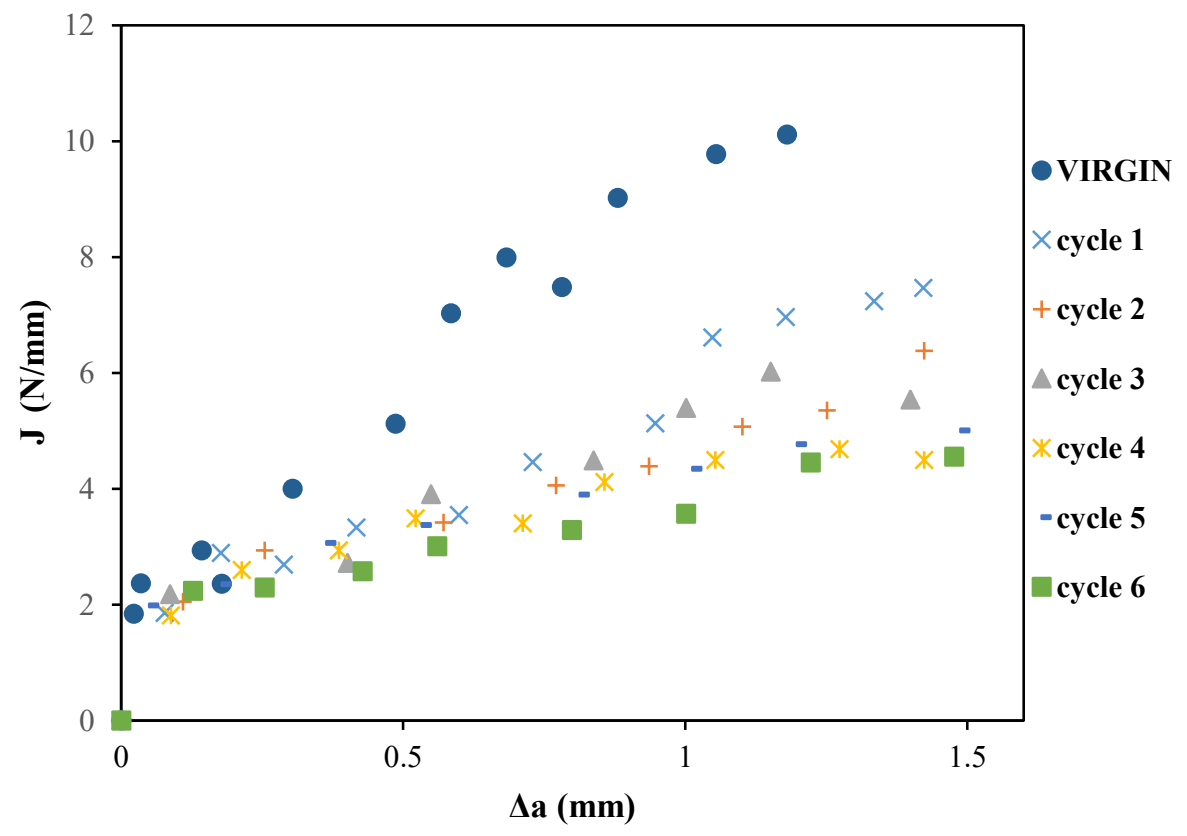

Fig. 9: The J- $\Delta$ a curve of recycled HIPS during different cycles. 


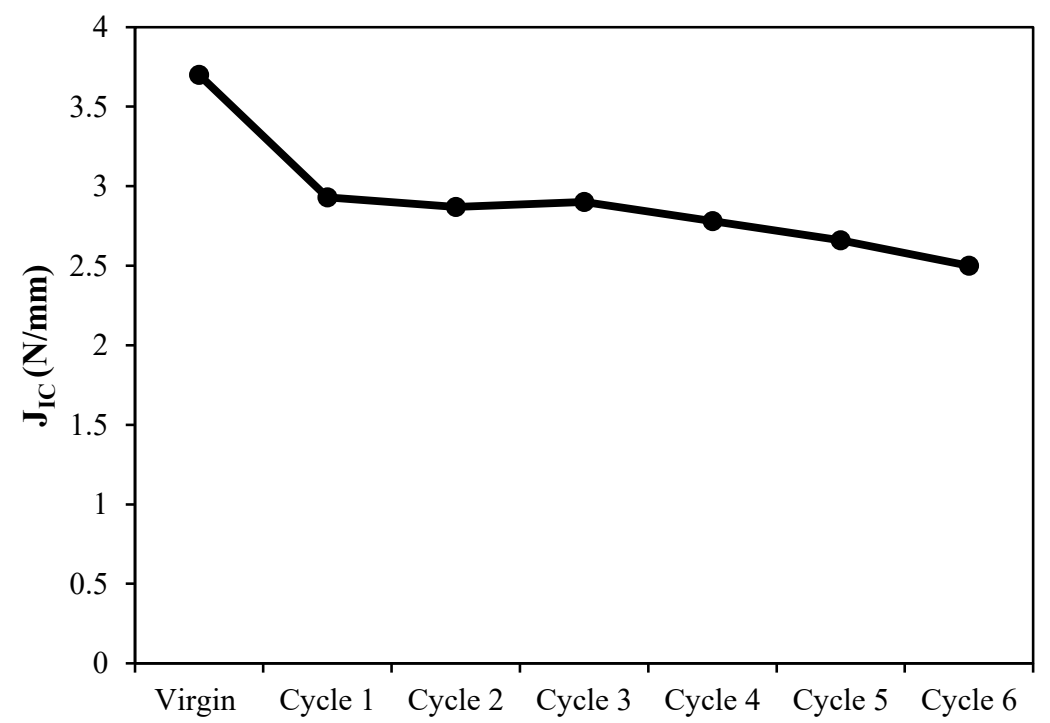

Fig. 10: The evolution of $\mathrm{J}_{\mathrm{IC}}$ as a function of number of cycles.

\section{Degradation During Recycling/Extrusion}

It is well known that extrusion is one of the most severe processes that a polymer can withstand [33], shear forces and high temperatures cause mechanical and thermal splitting of the polymer chain, resulting in the formation of end of chain radicals (initiation of propagation phenomenon) as shown in Fig. 11.

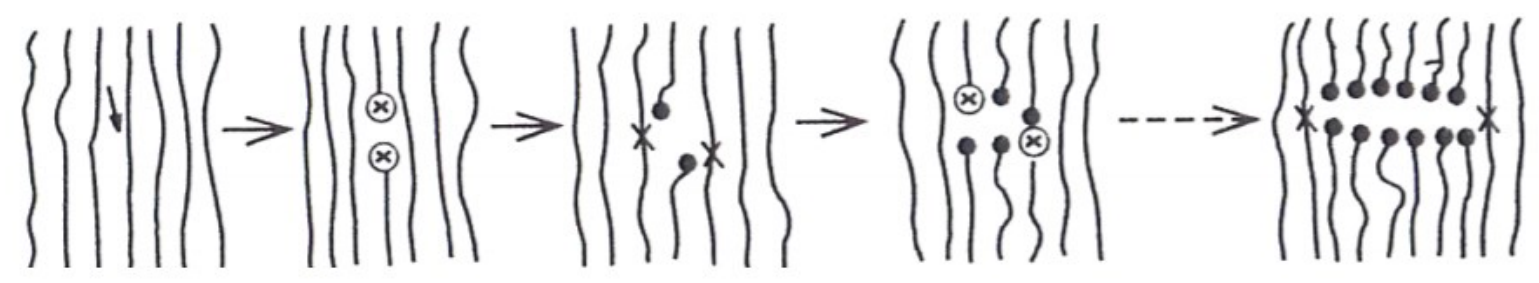

Fig. 11: Splitting of the polymer chains due to mechanical and thermal degradation.

Polymers are generally recycled in the molten state, at a temperature above the melting temperature but obviously well below the decomposition temperature. This does not prevent thermal and mechanical degradation from prevailing during the short implementation period (processing):

- thermal: the high friction shear can locally increase the temperature above the nominal processing temperature and chemical bonds can be thermally strained until they break.

- mechanical: when the rate of deformation of chemical bonds is much greater than the rate of relaxation of macromolecules, the activation energy of the fracture of the bonds and consequently the induced degradation time $\left(t_{i}\right)$, are reduced to the intensity of the applied stresses.

The consequence of such degradation is the reduction in molar mass by $1 / 2,1 / 4$, or $1 / 8$ of the initial molar mass [34], in fact, the molar mass of polymers plays a significant role in terms of durability. It has been generally recognized that high impact polystyrene becomes more stable when its molar mass increases or when the fraction of low masses decreases. Shorter chains result in a greater number of chain ends. These ends provide elements very 
sensitive to aging and to degradation in general. They are even capable of locally catalyzing degradation reactions.

A high molar mass induces the following properties:

- an increase in the entanglement rate (knots) which serves to counter the propagation of cracks in the material

- a drop in gas permeability and therefore a drop in the progression of reactive elements through the material [35].

Our previous work [36] on characterizing of multi-recycled high impact polystyrene indicated an increase of the Melt Flow Index as well as a decrease in molecular weight which supports the results of the present paper.

\section{CONCLUSION}

The study of the mechanical properties, in particular the fracture behavior of multirecycled high impact polystyrene from disposable cups, allowed us to specify the influence of the degradation phenomenon on the drop in $\mathrm{J}_{\mathrm{IC}}$ values. Mechanical degradations in the recycling/processing of polymers have been the least studied, no doubt because of their complexity; however, they play a very important role and their control is essential in the recycling operation. The growing demand from users for the quality and reliability of plastics, gives the study of degradation an increasingly important place, particularly from the perspective of recycling, which is becoming more and more inevitable.

The multi-specimen method based on Elastoplastic Fracture Mechanics, revealed a slight degradation in terms of fracture resistance, of the various recyclates, especially during the first cycle, this is explained by chain breaking, oxidation, and decreasing of the molar mass of high impact polystyrene. On the other hand, the present analysis strongly supports our previous work on the effect of multi-recycling on the material-flowing index as it showed an increase in melting flow index and therefore the decrease in viscosity with the number of recycling cycles.

\section{REFERENCES}

[1] Azwa ZN,Yousif BF,Manalo AC, Karunasena W. (2013), A review on the degradability of polymeric composites based on natural fibres, Materials \& Design, 47(1): 424-442. https://doi.org/10.1016/j.matdes.2012.11.025

[2] Celina M, Linde E, Brunson D, Quintana A, Giron N. (2019) Overview of accelerated aging and polymer degradation kinetics for combined radiation-thermal environments, Polymer Degradation and Stability,166 (1): 353-378.

https://doi.org/10.1016/j.polymdegradstab.2019.06.007

[3] Saikrishnan S, Jubinville D, Tzoganakis C, Mekonnen TM. (2020) Thermo-mechanical degradation of polypropylene (PP) and low-density polyethylene (LDPE) blends exposed to simulated recycling. Polymer Degradation and Stability, 182(1). https://doi.org/10.1016/j.polymdegradstab.2020.109390

[4] Ito M, Nagai K. (2008) Degradation issues of polymer materials used in railway field, Polymer Degradation and Stability, 93(10): 1723-1735.

https://doi.org/10.1016/j.polymdegradstab.2008.07.011

[5] Verdu J. (2011) Vieillissement chimique des plastiques : aspects généraux, Techniques de l'Ingénieur. https://www.techniques-ingenieur.fr/base-documentaire/archives-th12/archivesplastiques-et-composites-tiaam/archive-1/vieillissement-chimique-des-plastiques-aspectsgeneraux-am3151/ 
[6] Vranjes N, Rek V. (2007) Effect of EPDM on morphology, mechanical properties, crystallization behavior and viscoelastic properties. Macromolecular Symposia, 258(1): 90100. https://doi.org/10.1002/masy.200751210

[7] Kallel T, Massardier-Nageotte V, Jaziri M, Gérard J F, Elleuch B. (2003) Compatibilization of $\mathrm{PE} / \mathrm{PS}$ and PE/PP blends. I. Effect of processing conditions and formulation. Journal of Applied Polymer Science, 90(9): 2475-2484. https://doi.org/10.1002/app.12873

[8] Lin Y, Marchand G R, Hiltner A, Baer E. (2011) Adhesion of olefin block copolymers to polypropylene and high density polyethylene and their effectiveness as compatibilisers in blends. Polymer, 52(7) :1635-1644. https://doi.org/10.1016/j.polymer.2011.02.012

[9] Siddiqui M, Antonakou E, Redhwi H, Achilias D. (2019) Kinetic analysis of thermal and catalytic degradation of polymers found in waste electric and electronic equipment. Thermochimica Acta, 675 (1): 69-76. https://doi.org/10.1016/j.tca.2019.03.001.

[10] Sawaguchi T, Sasaki D, Takamura A. (2019) On the entanglement-based mechanism in thermal degradation of vinyl polymers, Polymer Degradation and Stability, 169(1): 108990. DOI: https://doi.org/10.1016/j.polymdegradstab.2019.108990.

[11] Hirayama D, Clodoaldo S. (2018) Morphologic and mechanical properties of blends from recycled acrylonitrile-butadiene-styrene and high-impact polystyrene, Polymer, 135 (1): 271278. https://doi.org/10.1016/j.polymer.2017.12.038.

[12] Lin Y, Yakovleva V, Chen H, Hiltner A, Baer E. (2009) Comparison of olefin copolymers as compatibilizers for polypropylene and high-density polyethylene. Journal of Applied Polymer Science, 113(3): 1945-1952. https://doi.org/10.1002/app.30190

[13] Zweifel H. (2000) Plastics Additives Handbook Munich. Hanser. (5th Edition) :900.

[14] Mehrabzadeh M, Farahmand F. (2001) Recycling of commingled plastics waste containing polypropylene, polyethylene, and paper. Journal of Applied Polymer Science. 80(13): 25732577. https://doi.org/10.1002/app.1367

[15] Ku H, Wang N, Pattarachaiyakoop N, Trada M. (2011) A review on the tensile properties of natural fiber reinforced polymers composites. Composites, Part B,42(4): 856-873. https://doi.org/10.1016/j.compositesb.2011.01.010

[16] Grein C, Gahleitner M, Bernreitner K. (2012) Mechanical and optical effects of elastomer interaction in polypropylene modification: ethylene-propylene rubber, poly-(ethylenecooctene) and styrene-butadiene elastomers. eXPRESS Polymer Letters, 6(9): 688-696.

DOI: 10.3144 /expresspolymlett.2012.74

[17] Ubonnut L, Thongyai S, Praserthdam P. (2007) Interfacial adhesion enhancement of polyethylene-polypropylene mixtures by adding synthesized diisocyanate compatibilizers. Journal of Applied Polymer Science,104(6): 3766-3773. https://doi.org/10.1002/app.25945

[18] Radonjic G, Gubeljak N. (2002) The use of ethylene/propylene copolymers as compatibilizers for recycled polyolefin blends. Macromolecular Material and Engineering, 2(287): 122-132. https://doi.org/10.1002/1439-2054(20020201)287:2<122::AID-MAME122>3.0.CO;2-A

[19] Colbeaux A, Kotek J, Fenouillot F, Taha M, Wautier H, Gérard J F. (2001) Compatibilisation de mélanges polypropylène/polyéthylène par extrusion réactive. Thèse doctorat INSA Lyon, 338 p. http://theses.insa-lyon.fr/publication/2001ISAL0058/these.pdf

[20] Almishal S, Mohamed T, Shazly M. (2020) Experimental and statistical study of the effect of temperature and waste ratio on the mechanical properties and cost of polystyrene polypropylene plastic blends, Heliyon, 6(6): e04166. https://doi.org/10.1016/j.heliyon.2020.e04166.

[21] Mehat NM, Kamaruddin S. (2011) Optimization of mechanical properties of recycled plastic products via optimal parameters using the Taguchi methods. Journal of Materials Processing Technology, 211(12): 1989-1994. https://doi.org/10.1016/j.jmatprotec.2011.06.014

[22] Krulis Z, Kokta V B, Horak Z, Michalkova D, Fortelny I. (2001) Compatibilization as a procedure for recycling of commingled polyolefin waste. Macromolecular Materials and Engineering, 286(3): 156-160. https://doi.org/10.1002/1439-2054(20010301)286:3<156::AID-MAME156>3.0.CO;2-J

[23] Ritchie R, Liu D. (2021) Chapter 2 - Foundations of fracture mechanics, Introduction to Fracture Mechanics, Elsevier: 3-9. https://doi.org/10.1016/B978-0-323-89822-5.00008-6.

[24] Irwin GR. (1957) Analysis of stresses and strains near the end of a crack traversing a plate, Journal of Applied Mechanics, 24:361-364. 
[25] Rice JR. (1968) A path independent integral and approximate analysis of strain concentration by notches and cracks. Journal of Applied Mechanics, 35(2):379-386. DOI: $10.1115 / 1.3601206$

[26] Begley JA, Landes JD. (1971) The effect of specimen geometry in JIc. Fracture toughness, American Society of Testing and Materials, Special Technical Publication, 514: 24-39. https://doi.org/10.1520/STP38817S

[27] Begley JA, Landes JD. (1971) The J-integral as a fracture criterion. Fracture toughness, American Society of Testing and Materials, Special Technical Publication, 514: 1-23. https://doi.org/10.1520/STP38816S

[28] Begley JA, Landes JD. (1974) Test Results from J-lntegral Studies: An Attempt to Establish a JIC Testing Procedure. Fracture Analysis, American Society for Testing and Materials, Special Technical Publication, 560:170-186. https://doi.org/10.1520/STP33140S

[29] Brosa V, Bernal C, Frontini P. (1999) Calibration of fracture mechanics parameters and J-R curve determination in polyethylene side-grooved arc-shaped specimens. Eng. Fract. Mech,62(2-3): 231-248. https://doi.org/10.1016/S0013-7944(98)00094-0

[30] Clarke G, Landes J. (1979) Evaluation of the J Integral for the Compact Specimen. J. Test. Eval,7(5): 264-269. https://doi.org/10.1520/JTE10222J

[31] Tancrez J, Pabiot J, Rietsch F. (1996) Damage and fracture mechanisms in thermoplasticmatrix composites in relation to processing and structural parameters. Compos. Sci. Technol, 56(7): 725-731. https://doi.org/10.1016/0266-3538(96)00013-9

[32] Huang D. (1996) The application of fracture mechanics to materials selection. Polym. Eng. Sci, 36(18): 2270-2274. https://doi.org/10.1002/pen.10625

[33] Kumar S, Singh R. (2003) Primary and Secondary Recycling of Thermosetting Polymers: A Review. Reference Module in Materials Science and Materials Engineering, 73(9): 1775. https://doi.org/10.1002/mame.200390005

[34] Wrozynski RJ, Rubinsztajn M, Potyrailo RA. (2004) Evaluation of Process Degradation of Polymer Formulations Utilizing High-Throughput Preparation and Analysis Methods. Macromolecular rapid communication, 2(1): 264-269. https://doi.org/10.1002/marc.200300167

[35] Bartolomeo P. (2003) Deriving a prediction of the life cycle of géosynthrtic polymers. Bulletins des laboratoires des Pont et Chaussées, $\mathrm{N}^{\circ} 243$-Réf 4456, p.51. 